\title{
PENDAMPINGAN GURU DAN PESERTA DIDIK DALAM PEMBELAJARAN IPA TERPADU DI SMP
}

\author{
MENTORING OF TEACHERS AND STUDENTS IN LEARNING \\ INTEGRATED NATURAL SCIENCE IN YUNIOR HIGH SCHOOL
}

\author{
Usmeldi $^{{ }^{*}}$, Risda Amini ${ }^{1}$, Asrizal $^{2}$ \\ ${ }^{1}$ FT Universitas Negeri Padang, Jln. Hamka, Air Tawar, Padang, Sumatera Barat \\ ${ }^{2}$ FMIPA Universitas Negeri Padang, Jln. Hamka, Air Tawar, Padang, Sumatera Barat \\ *Email: usmeldy@yahoo.co.id
}

(Diterima 30-07-2021; Disetujui 23-08-2021)

\begin{abstract}
ABSTRAK
Pelajaran Ilmu Pengetahuan Alam (IPA) di Sekolah Menengah Pertama dalam Kurikulum 2013 dikembangkan sebagai mata pelajaran IPA terpadu. IPA terpadu mempunyai makna memadukan konsepkonsep IPA dari fisika, biologi, kimia, ilmu pengetahuan bumi dan antariksa. Hasil survei awal di sekolah mitra menunjukkan bahwa: (1) Guru belum memahami dengan baik materi IPA terpadu dan pengembangan bahan ajarnya. (2) Masih banyak peserta didik kesulitan menyelesaikan soal-soal IPA terpadu. (3) Masih banyak peserta didik yang belum tuntas dalam belajar IPA. (4) Masih banyak peserta didik yang tidak mau bertanya pada guru pada saat belajar IPA. Solusi yang ditawarkan dalam memecahkan masalah prioritas mitra adalah pendampingan menyusun modul IPA terpadu bagi guru IPA dan membahas soal-soal IPA terpadu bagi peserta didik. Tujuan kegiatan pendampingan adalah guru mampu menyusun modul IPA terpadu berbasis riset dan peserta didik mampu menyelesaikan soal-soal IPA terpadu. Metode yang digunakan adalah metode ceramah, diskusi, latihan, dan praktik yang berorientasi pada pencapaian hasil. Pada awal pendampingan dilakukan diskusi untuk mengetahui pengetahuan awal peserta tentang penguasaan materi pelajaran IPA terpadu. Peserta didik kelas IX didampingi oleh tim pelaksana dalam membahas soal-soal IPA terpadu, pada saat belajar tambahan. Pada akhir kegiatan pendampingan, guru IPA melakukan uji coba modul pembelajaran pada peserta didik. Peserta didik mengikuti tes penguasaan materi IPA terpadu. Hasil pendampingan guru dan peserta didik dalam pembelajaran IPA terpadu adalah: (1) Materi pelatihan dapat dikuasai oleh peserta (guru IPA), baik pengetahuan maupun keterampilan membuat modul pembelajaran IPA terpadu berbasis riset. (2) Terdapat peningkatan kemampuan peserta didik menguasai materi pembelajaran IPA terpadu.
\end{abstract}

Kata kunci: Hasil belajar, IPA terpadu, modul pembelajaran

\section{ABSTRACT}

Natural Science lessons in Junior High Schools in the 2013 Curriculum were developed as integrated science subjects. Integrated natural science has the meaning of combining science concepts from physics, biology, chemistry, earth and space science. The results of the initial survey in partner schools show that: (1) Teachers do not understand well the integrated science materials and the development of teaching materials. (2) There are still many students who have difficulty solving integrated science questions. (3) There are still many students who have not finished learning science. (4) There are still many students who do not want to ask the teacher when learning science. The solution offered in solving partner priority problems is assistance in compiling integrated science materials for science teachers and discussing integrated science questions for students. The objectives to be achieved in this mentoring activity are that teachers are able to compile integrated science materials and students are able to solve integrated science questions. The method used is the method of lectures, discussions, drills, and practice that is oriented towards achieving results. At the beginning of the mentoring, a discussion was held to determine the participants' initial knowledge about mastering integrated science subject matter. Class IX students are accompanied by an implementation team in solving integrated science questions, during additional study. At the end of the mentoring activity, the science teacher tested the learning module on the students. Students take the integrated science mastery test. The results of mentoring teachers and students in integrated science learning are: (1) The training materials can be mastered by participants (science teachers), both knowledge and skills in making research-based integrated science learning modules. (2) There is an increase in the ability of students to master integrated science learning materials.

Keywords: Learning outcomes, integrated science, learning modules 
Pendampingan Guru dan Peserta Didik dalam Pembelajaran IPA Terpadu di SMP

Usmeldi, Risda Amini, Asrizal

\section{PENDAHULUAN}

Dalam Pedoman Pengembangan Kurikulum 2013 disebutkan bahwa pembelajaran IPA di SMP dilaksanakan secara terpadu yang mempunyai makna memadukan domain sikap, pengetahuan, dan keterampilan (Mamat, 2005). Pembelajaran IPA terpadu memberikan kesempatan kepada peserta didik untuk mengembangkan kemampuan berpikir, keterampilan proses, dan pengembangan sikap ilmiah. Konsep keterpaduan ini ditunjukkan dalam Kompetensi Inti (KI) dan Kompetensi Dasar (KD) pembelajaran IPA yakni dalam satu KD sudah memadukan materi IPA dari bidang fisika, biologi, kimia, ilmu pengetahuan bumi dan antariksa (IPBA). Menurut Hewitt (2007) dan Kemdiknas (2010) IPA terpadu menyajikan aspek fisika, kimia, biologi, ilmu bumi, dan astronomi. IPA terpadu disajikan berbasis pendekatan kontekstual yaitu menghubungkan IPA dengan kehidupan sehari-hari, bersifat personal dan langsung, menempatkan salah satu ide pokok, dan mengandung pemecahan masalah. Dalam pembelajaran, IPA disajikan dengan kesatuan konsep.

Pembelajaran terpadu telah dikemukakan oleh John Dewey sebagai upaya untuk mengintegrasikan perkembangan dan pertumbuhan peserta didik dan kemampuan pengetahuannya (Sa'ud, 2006). Ia memberikan pengertian bahwa pembelajaran terpadu adalah pendekatan untuk mengembangkan pengetahuan peserta didik dalam pembentukan pengetahuan berdasarkan pada interaksi dengan lingkungan dan pengalaman kehidupannya. Hal ini membantu peserta didik untuk belajar menghubungkan apa yang telah dipelajari dan apa yang sedang dipelajari. Menurut Rakajoni (Trianto, 2007) bahwa pembelajaran terpadu merupakan sistem pembelajaran yang memungkinkan peserta didik secara individual maupun kelompok aktif mencari, menggali, dan menemukan konsep serta prinsip keilmuan secara holistik, bermakna, dan autentik. Menurut Subroto (Trianto, 2007) pembelajaran terpadu adalah pembelajaran yang diawali dengan tema tertentu yang dikaitkan dengan pokok bahasan lain, konsep tertentu dikaitkan dengan konsep lain, yang dilakukan secara spontan atau direncanakan, baik dalam satu bidang studi atau lebih, dan dengan beragam pengalaman belajar peserta didik, maka pembelajaran menjadi lebih bermakna. Karli (2009) dan Jafari (2012) dalam penelitiannya menemukan bahwa pembelajaran terpadu memudahkan peserta didik memahami konsep-konsep secara holistik dibandingkan dengan pembelajaran secara terpisah. Pada umumnya pembelajaran terpadu adalah pembelajaran yang menggunakan tema untuk mengaitkan antara beberapa materi pelajaran dengan pengalaman kehidupan nyata sehari-hari peserta didik, sehingga dapat memberikan pengalaman bermakna bagi mereka. Jihad (2008) dan Sugiyar (2009) 
menyatakan bahwa pembelajaran terpadu adalah model pembelajaran yang mengintregasikan beberapa mata pelajaran dengan tema tertentu untuk memberikan pengalaman bermakna kepada peserta didik.

Pada Kurikulum 2013, KD mata pelajaran IPA sudah memadukan konsep dari aspek fisika, biologi, kimia, dan IPBA, tetapi tidak semua aspek dipadukan karena pada suatu topik IPA tidak semua aspek dapat dipadukan. Dari sejumlah model pembelajaran yang dikemukakan Fogarty (1991), terdapat beberapa model yang potensial untuk diterapkan dalam pembelajaran IPA terpadu, yaitu connected, webbed, shared, dan integrated. Empat model tersebut dipilih karena konsep-konsep dalam KD mata pelajaran IPA memiliki karakteristik yang berbeda-beda, sehingga memerlukan model yang sesuai agar memberikan hasil keterpaduan yang optimal. Ada sejumlah konsep yang saling bertautan dalam satu KD. Agar pembelajarannya menghasilkan kompetensi yang utuh, maka konsepkonsep tersebut harus dipertautkan (connected) dalam pembelajarannya. Pada model connected ini konsep pokok menjadi materi pembelajaran inti, sedangkan contoh atau terapan konsep yang dikaitkan berfungsi untuk memperkaya. Ada KD yang mengandung konsep saling berkaitan tetapi tidak beririsan. Untuk menghasilkan kompetensi yang utuh, konsep-konsep harus dikaitkan dengan suatu tema tertentu hingga menyerupai jaring labalaba. Model semacam ini disebut webbed (Handayani, 2011). Karena selalu memerlukan tema pengait, maka model webbed lazim disebut model tematik. Ada sejumlah KD yang mengandung konsep saling beririsan/ tumpang tindih, sehingga bila disajikan secara terpisah menjadi tidak efisien. Konsep-konsep semacam ini memerlukan pembelajaran model integrated atau shared. Pada model integrated, materi pembelajaran dikemas dari konsep-konsep dalam KD yang sepenuhnya beririsan, sedangkan pada model shared, konsep-konsep dalam KD yang dibelajarkan tidak sepenuhnya beririsan, tetapi dimulai dari bagian yang beririsan.

Hasil survei awal di sekolah mitra (SMP Negeri 2 Padang) menunjukkan bahwa: (1) Guru belum memahami dengan baik materi IPA terpadu dan pengembangan bahan ajarnya. (2) Guru yang diberi tugas mengajar IPA tidak memiliki latar belakang pendidikan IPA, tetapi berasal dari pendidikan fisika, pendidikan biologi, dan pendidikan kimia. (3) Guru belum menerapkan pembelajaran yang melibatkan aktivitas peserta didik dalam menemukan fakta, konsep, prinsip, dan hukum dalam pelajaran IPA. (4) Masih banyak peserta didik kesulitan menyelesaikan soal-soal IPA terpadu. (5) Masih banyak peserta didik yang belum tuntas dalam belajar IPA. (6) Masih banyak peserta didik yang tidak mau bertanya pada guru pada saat belajar IPA. 
Berdasarkan hasil survey, ditetapkan prioritas masalah yang akan ditanggulangi dengan segera, yaitu melaksanakan kegiatan pendampingan menyusun materi IPA terpadu bagi guru IPA dan membahas soal-soal IPA terpadu bagi peserta didik di sekolah mitra. Materi IPA terpadu disusun dalam bentuk modul pembelajaran berbasis riset. Pembelajaran berbasis riset merupakan salah satu model student-centered learning yang mengintegrasikan riset di dalam proses pembelajaran. Pembelajaran berbasis riset mengacu pada berbagai macam metode pembelajaran. Pembelajaran berbasis riset memberi kesempatan kepada peserta didik untuk mencari informasi, menyusun hipotesis, mengumpulkan data, menganalisis data, dan membuat kesimpulan (Wardoyo, 2013). Model pembelajaran berbasis riset dikembangkan sesuai dengan karakteristik mata pelajaran dan kondisi fasilitas yang tersedia. Model pembelajaran berbasis riset telah dikembangkan oleh Usmeldi dan Risda Amini (2017) dalam penelitian tim pascasarjana dengan tahapan sebagai berikut: (1) mengidentifikasi dan merumuskan masalah, (2) mengkaji literatur, (3) merumuskan hipotesis, (4) mengumpulkan dan menganalisis data, (5) menginterpretasi dan menyimpulkan hasil riset, (6) melaporkan dan mengkomunikasikan hasil riset. Pelaksanaan riset dipandu oleh lembar kegiatan peserta didik. Laporan riset dalam bentuk makalah sederhana. Hasil riset dipresentasikan oleh setiap kelompok peserta didik. Tujuan kegiatan pendampingan adalah (1) supaya guru IPA di sekolah mitra mampu mengembangkan materi IPA terpadu dalam bentuk modul pembelajaran berbasis riset, (2) untuk meningkatkan kemampuan peserta didik dalam menyelesaikan soal-soal IPA.

\section{BAHAN DAN METODE}

Metode pelaksanaan kegiatan pendampingan adalah ceramah, diskusi, demonstrasi, dan praktik yang berorientasi pada pencapaian hasil berupa modul pembelajaran IPA terpadu berbasis riset. Peserta pendampingan adalah guru IPA SMP Negeri 2 Padang yang berjumlah 5 orang dan peserta didik kelas IX yang berjumlah 8 kelas. Pendampingan untuk guru IPA dilaksanakan setiap hari Sabtu di SMP Negeri 2 Padang. Waktu pendampingan dialokasikan dengan proporsi $20 \%$ untuk teori (penjelasan materi pelatihan) dan $80 \%$ untuk praktik (membuat dan menguji coba modul pembelajaran). Tugas mandiri menyelesaikan modul pembelajaran dilakukan selama dua bulan. Pendampingan membahas soal-soal IPA terpadu untuk peserta didik dilaksanakan setiap hari Sabtu dengan jadwal belajar tambahan. 
Langkah-langkah kegiatan pendampingan adalah: (1) Melakukan diskusi untuk mengetahui pengetahuan awal peserta pelatihan (guru IPA) tentang penguasaan materi IPA terpadu. (2) Memberikan penjelasan tentang materi IPA terpadu. (3) Melakukan lokakarya untuk menyusun tema IPA terpadu. (4) Memberikan penjelasan tentang pengembangan modul pembelajaran IPA terpadu berbasis riset. (5) Membimbing peserta pelatihan mengembangkan modul IPA terpadu berbasis riset. (6) Peserta pelatihan melakukan uji coba modul pembelajaran pada peserta didik SMP. (7) Membimbing peserta didik membahas soal-soal IPA terpadu. (8) Mengevaluasi proses pendampingan. (9) Mengevaluasi hasil kegiatan pendampingan berupa modul pembelajaran IPA terpadu berbasis riset dan kemampuan peserta didik menyelesaikan soal-soal IPA terpadu. Data kegiatan pelatihan dikumpul menggunakan lembar observasi, angket, dan tes hasil belajar peserta didik. Data dianalisis dengan teknikpersentase dan katergori skor.

\section{HASIL DAN PEMBAHASAN}

\section{Hasil}

Sebelum penyajian materi pelatihan dilakukan penjajagan (braimstorming) untuk mengetahui kemampuan awal peserta melalui angket dan diskusi. Hasil penjajagan menunjukkan bahwa sebagian besar (60\%) peserta pelatihan (guru IPA) belum mengembangkan modul pembelajaran. Selama ini peserta pelatihan telah menggunakan modul pembelajaran yang diunduh melalui internet. Sebagian besar (80\%) peserta pelatihan belum menyusun tema IPA terpadu. Hasil tes awal menunjukkan bahwa sebagian besar peserta didik (83\%) belum menguasai materi IPA terpadu. Berdasarkan hasil penjajagan maka kegiatan diprioritaskan untuk melatih guru IPA menyusun tema pembelajaran IPA terpadu dan mengembangkan modul pembelajaran IPA terpadu berbasis riset. Peserta didik diberi pendampingan membahas soal-soal IPA terpadu oleh mahasiswa Pendidikan IPA FMIPA Universitas Negeri Padang yang dilibatkan dalam Program Kemitraan Masyarakat.

Setelah pembukaan oleh kepala SMP Negeri 2 Padang dan braimstorming, acara dilanjutkan dengan penyajian materi IPA terpadu. Setelah materi selesai disampaikan, dilanjutkan dengan diskusi. Semua peserta pelatihan berpartisipasi dalam diskusi, sehingga diskusi berjalan dengan lancar. Kegiatan pelatihan dilanjutkan dengan diskusi penentuan tema IPA terpadu. Kegiatan selanjutnya adalah praktik menyusun desain modul pembelajaran IPA terpadu berbasis riset secara bersama-sama. Peserta pelatihan sangat 
antusias terhadap materi kegiatan pelatihan. Hal ini terlihat dari awal hingga akhir kegiatan, semua peserta mengikuti dengan baik.

Pelaksanaan kegiatan pendampingan sangat membantu peserta dalam menyusun modul pembelajaran IPA terpadu berbasis riset. Pencapaian hasil pelaksanaan kegiatan pendampingan dapat dilihat dari aspek tujuan dan manfaat pelaksanaan kegiatan. Tujuan yang telah ditetapkan yaitu peserta pelatihan mampu menghasilkan modul pembelajaran IPA terpadu berbasis riset sudah dicapai dengan baik. Peserta pelatihan sudah memiliki kemampuan membuat modul pembelajaran IPA terpadu berbasis riset yang dilengkapi dengan gambar, foto, dan soal latihan.

Setelah mengikuti kegiatan pelatihan, guru melaksanakan pembelajaran dengan modul pembelajaran IPA terpadu berbasis riset. Kemampuan guru melaksanakan pembelajaran tersebut ditunjang oleh meningkatnya pengetahuan dan keterampilan guru menyusun modul pembelajaran IPA terpadu berbasis riset. Keberhasilan pelaksanaan kegiatan pendampingan dapat dilihat dari penguasaan terhadap materi IPA terpadu, penyusunan modul pembelajaran IPA terpadu berbasis riset, dan kemampuan peserta didik menguasai materi IPA terpadu, seperti dalam tabel 1.

Tabel 1. Hasil Penilaian Kegiatan Pendampingan

\begin{tabular}{llc}
\hline No. & \multicolumn{1}{c}{ Aspek yang dinilai } & Rata-rata hasil penilaian \\
\hline 1 & $\begin{array}{l}\text { Kemampuan guru menyusun tema pembelajaran IPA } \\
\text { terpadu }\end{array}$ & Baik \\
2 & $\begin{array}{l}\text { Kemampuan guru mendesain modul pembelajaran IPA } \\
\text { terpadu berbasis riset }\end{array}$ & Baik \\
3 & $\begin{array}{l}\text { Kemampuan guru menyusun modul pembelajaran IPA } \\
\text { terpadu berbasis riset }\end{array}$ & Baik \\
4 & $\begin{array}{l}\text { Kemampuan guru membuat evaluasi dalam modul } \\
\text { pembelajaran IPA terpadu berbasis riset }\end{array}$ \\
5 & $\begin{array}{l}\text { Kemampuan guru menguasai materi IPA terpadu } \\
\text { Peningkatan kemampuan peserta didik menguasai materi }\end{array}$ & $\begin{array}{c}\text { Baik } \\
\text { Tinggi }\end{array}$ \\
\hline
\end{tabular}

Uji coba terbatas melibatkan peserta didik di kelas oleh masing-masing peserta pelatihan (guru IPA). Waktu yang disediakan bagi peserta untuk melaksanakan ujicoba terbatas adalah dua minggu. Setelah pelaksanaan uji coba terbatas melalui pembelajaran dengan modul pembelajaran IPA terpadu berbasis riset, peserta pelatihan menyempurnakan modul pembelajaran IPA terpadu berbasis riset.

Pada akhir kegiatan dilakukan penjaringan tanggapan peserta menggunakan angket sebagai upaya mengetahui kesulitan dan pendapat peserta pelatihan tentang kegiatan yang telah dilakukan. Hasil tanggapan peserta pelatihan atas kegiatan yang telah dilakukan 
adalah: (1) Pelatihan sangat bermanfaat dan dapat meningkatkan pengetahuan dan keterampilan peserta dalam membuat modul pembelajaran IPA terpadu berbasis riset. (2) Penggunaan modul pembelajaran IPA terpadu berbasis riset dapat memotivasi siswa untuk belajar lebih baik. (3) Materi pelatihan dapat diterapkan dalam pembelajaran berbasis riset. (4) Peserta pelatihan menyarankan supaya pelatihan dilanjutkan dan dikembangkan ke penerapan teknologi informasi dan komunikasi (TIK) dalam membuat modul pembelajaran.

\section{Pembahasan}

Hasil penjajagan kemampuan awal peserta pendampingan menunjukkan bahwa sebagian besar peserta belum menyusun tema IPA terpadu dan belum mengembangkan modul pembelajaran. Kemampuan awal peserta perlu diketahui untuk menjadi dasar pelaksaaan kegiatan pendampingan sehingga sesuai dengan kebutuhan peserta (Husamah,et.al., 2018; Sim,et.al, 2018; Wijayanti,et.al., 2019; Yayuk, 2019).

Berdasarkan hasil kegiatan pendampingan dan uji coba yang dilakukan pada peserta didik ditemukan bahwa kesiapan guru, peserta didik, dan fasilitas sangat menentukan keberhasilan pelaksanaan pembelajaran. Dari sisi guru, kemampuan menentukan tema, memadukan materi fisika, kimia, dan biologi, serta mengusai materi IPA terpadu yang beragam merupakan faktor yang penting dicermati. Hal ini karena guru IPA tidak memiliki latar belakang pendidikan IPA, tetapi berasal dari pendidikan fisika, pendidikan biologi, dan pendidikan kimia. Permasalahan ini sudah menjadi kajian utama oleh peneliti pendidikan IPA untuk membantu guru IPA (Gunawan et al., 2019; Rubini,et.al., 2019; Gunawan et al., 2020). Respon guru terhadap pelaksanaan pendampingan ini adalah sangat baik sehingga pengembangan modul pembelajaran IPA terpadu dapat terlaksana (Gunawan, 2021). Peningkatan kompetensi guru di sekolah mitra ditunjukkan oleh indikator kemampuan menguasai langkah-langkah penyusunan modul pembelajaran (Zuriah, 2016; Nasir,et.al., 2019).

Dari sisi peserta didik ditemukan bahwa sebagian besar peserta didik sudah mampu menguasai materi IPA terpadu, sehingga pelaksanaan uji coba dapat berjalan dengan lancar. Respon peserta didik terhadap modul pembelajaran IPA terpadu berbasis riset sangat baik. Hal ini sejalan dengan temuan Latifah \& Ratnasari (2016), Novitasari,et.al. (2016), dan Budaeng,et.al. (2017) yang menyatakan bahwa respon peserta didik terhadap modul pembelajaran sangat baik untuk mendukung belajar mandiri atau kelompok. Di samping itu peserta didik merasa puas dan senang dalam pembelajaran dengan modul 
Pendampingan Guru dan Peserta Didik dalam Pembelajaran IPA Terpadu di SMP

Usmeldi, Risda Amini, Asrizal

pembelajaran, sebagaimana ditemukan oleh Astuti,et.al. (2016), Khoerunnisa,et.al. (2016), dan Nailiyah,et.al. (2016). Pembelajaran terpadu dapat meningkatkan keterampilan komunikatif (membaca, mendengar, berbicara, menulis), kemampuan kognitif, dan motivasi peserta didik (Listyawati, 2012; Dallinger, 2016).

\section{KESIMPULAN DAN SARAN}

Kegiatan pelatihan dan pendampingan dapat meningkatkan kemampuan peserta (guru IPA) dalam mengembangkan modul pembelajaran IPA terpadu berbasis riset, sehingga dapat memotivasi peserta didik dalam belajar. Modul pembelajaran IPA terpadu berbasis riset yang dibuat peserta pelatihan dilengkapi dengan gambar, foto, soal latihan, dan evaluasi. Hasil evaluasi menunjukkan bahwa materi pelatihan dapat dikuasai oleh peserta, baik pengetahuan maupun keterampilan mengembangkan modul pembelajaran IPA terpadu berbasis riset. Keberhasilan ini ditunjang oleh: (1) Adanya kesesuaian materi pelatihan dengan kebutuhan peserta. (2) Adanya respon yang positif dari peserta. (3) Sebagian besar peserta telah mempunyai keterampilan dalam mengembangkan perangkat pembelajaran IPA terpadu berbasis riset untuk meningkatkan kualitas pembelajaran. Hasil pendampingan terhadap peserta didik dalam membahas soal-soal IPA terpadu menunjukkan bahwa terdapat peningkatan kemampuan peserta didik menguasai materi pembelajaran IPA terpadu. Pengabdi selanjutnya disarankan melakukan pelatihan dan pendampingan penerapan teknologi informasi dan komunikasi dalam membuat modul pembelajaran.

\section{UCAPAN TERIMA KASIH}

Ucapan terima kasih disampaikan kepada Rektor Universitas Negeri Padang, Ketua Lembaga Penelitian dan Pengabdian kepada Masyarakat (LP2M) Universitas Negeri Padang, dan Kepala SMP Negeri 2 Padang yang telah memfasilitasi pelaksanaan kegiatan Program Kemitraan Masyarakat.

\section{DAFTAR PUSTAKA}

Astuti, R. A., Aminah, N. S., \& Sukarmin, S. (2016). Pengembangan modul ipa terpadu berbasis empat pilar pendidikan dengan tema pantai untuk meningkatkan sikap ilmiah siswa kelas VII SMP/MTS. Inkuiri, 5(2), 40-51.

Budaeng, J., Ayu, H. D., \& Pratiwi, H. Y. (2017). Pengembangan modul IPA/fisika terpadu berbasis scaffolding pada tema gerak untuk siswa kelas viii SMP/MTS. Momentum: Physics Education Journal, 31-44.

Dallinger, Sara (2016). The effect of content and language integrated learning on students' English and history competences. Journal Learning and Instruction, 41, 23-31. 
Fogarty, R. (1991). The Mindfull School: How to Integrate the Curricula. Palatine, Illinois: Sky-light Publishing, inc.

Gunawan, K. D. H., Liliasari, S., \& Kaniawati, I. (2019). Investigation of integrated science course process and the opportunities to implement CSCL learning environments Investigation of integrated science course process and the opportunities to implement CSCL learning environments, 71-77.

Gunawan, K. D. H., Liliasari, S., Kaniawati, I., \& Setiawan, W. (2020). Exploring Science Teachers ' Lesson Plans by the Implementation of Intelligent Tutoring Systems in Blended Learning Environments, 8(10), 4776-4783.

Gunawan,KDH., Liliasari, Kaniawati,I., Wawan Setiawan, Ketut Gunawan (2021). Respon guru dalam mendesain pembelajaran IPA terpadu berbantuan intelligent tutoring system: Evaluasi program pengabdian masyarakat (PPM) peningkatan kompetensi guru, Jurnal Widya Laksmi, 1(1), 7-12.

Handayani, S. (2011). Penerapan Model Pembelajaran Webbed untuk Meningkatkan Penguasaan Konsep IPA Siswa Kelas II Sekolah Dasar. Jurnal Studi Agama dan Masyarakat, Vol. 7(2).

Hewitt,PG; Suzanne A Lyons; John A. Suchocki; Jennifer Yeh (2007). Conceptual Integrated Science. California: Pearson Addison-Wesley.

Husamah, H., Hudha, A. M., \& Pantiwati, Y. (2018). Pendampingan guru SMPN 8 Kota Malang dalam mengembangkan perilaku etis siswa berbasis model pembelajaran OIDDE. International Journal of Community Service Learning, 2(2), 41-50.

Jafari, E., Nasrabadi, H.A., Liaghatdar, M.J. (2012). Holistic Education: An Approach for 21 Century. International Education Studies Vol. 5(2), p.178-186.

Jihad, Asep \& Abdul Haris (2008). Evaluasi Pembelajaran. Yogyakarta: Multi Press.

Karli, H. (2009). Pengembangan Model Pembelajaran Terpadu untuk Keterampilan Berpikir Rasional pada Pembelajaran IPA di SD. Tesis. Bandung: PPS UPI.

Kemdiknas (2010). Panduan Pengembangan Pembelajaran IPA Secara Terpadu. Jakarta: Direktorat Pembinaan Sekolah Menengah Pertama.

Khoerunnisa, R. F., Murbangun, N., \& Sudarmin, S. (2016). Pengembangan modul IPA terpadu etnosains untuk menumbuhkan minat kewirausahaan. Journal of Innovative Science Education, 5(1), 45-53.

Latifah, S., \& Ratnasari, R. (2016). Pengembangan modul IPA terpadu terintegrasi ayatayat Al-Qur'an pada materi tata surya. Jurnal Penelitian Pembelajaran Fisika, 7(1), 25-33.

Listyawati (2012). Pengembangan Perangkat Pembelajaran IPA Terpadu di SMP. Journal of Innovative Science, 1(1).

Mamat, SB., dkk. (2005). Pedoman Pelaksanaan Pembelajaran Tematik. Jakarta: Departemen Agama Direktorat Kelembagaan Agama Islam.

Nailiyah, M. R., Subiki, S., \& Wahyuni, S. (2016). Pengembangan modul IPA tematik berbasis etnosains kabupaten jember pada tema budidaya tanaman tembakau di SMP. Jurnal Pembelajaran Fisika, 5(3), 261-269.

Nasir,M., Nurcaya, Muhammad Nur (2019). Pendampingan musyawarah guru mata pelajaran (MGMP) IPA SMP untuk mengembangkan perangkat pembelajaran berbasis potensi lokal di Kabupaten Wajo, Sinar Sang Surya, 2(2), 1-8.

Novitasari, E., Masykuri, M., \& Aminah, N. S. (2016). Pengembangan modul pembelajaran ipa terpadu berbasis inkuiri terbimbing tema matahari sebagai sumber energi alternatif di kelas vii smp/mts. Inkuiri, 5(1), 112-121.

Rubini, B., Ardianto, D., \& Pursitasari, I. D. (2019). Teachers ' Perception Regardi ng Integrated Science Learning and Science Literacy, 253(Aes 2018), 364-366.

Sa'ud, Udin Syaefuddin, dkk. (2006). Pembelajaran Terpadu. Bandung: UPI Press. 
Sim, M., Nelayan, K., \& Madong, D. (2018). Pendampingan dalam operasionalisasi sistem informasi manajemen (SIM) kelompok nelayan Desa Madong. Journal of Maritime Empowerment, 1(1), 6-10.

Sugiyar, dkk. (2009). Pembelajaran Tematik. Surabaya: LAPIS-PGMI.

Trianto (2007). Model Pembelajaran Terpadu dalam Teori dan Praktek. Jakarta: Prestasi Pustaka.

Usmeldi dan Risda Amini (2017). Pengembangan Model Pembelajaran berbasis Riset untuk Meningkatkan Kompetensi Fisika Siswa SMA. Laporan Penelitian Tim Pascasarjana. Padang: UNP.

Wardoyo, Mangun Sigit (2013). Pembelajaran Berbasis Riset. Jakarta: Indeks Permata.

Wijayanti, D., Kurniawan, V. R. B., \& Susanto, D. (2019). Perancangan kemasan ramah lingkungan berbahan corugated dan penerapan sistem pemasaran daring pada produk jamu tradisional Kiringan. Abdimas Dewantara, 2(1), 45-52.

Yayuk,E. dan Santi Prastiyowati (2019). Pendampingan pembuatan perangkat pembelajaran kurikulum 2013, International Journal of Community Service Learning, 3(4), 222-232.

Zuriah, N., Sunaryo, H., \& Yusuf, N. (2016). IbM guru dalam pengembangan bahan ajar kreatif inovatif berbasis potensi lokal. Dedikasi, 13(1), 40-46. 